\title{
GENDER ISSUES IN CHARLOTTE BRONTE'S JANE EYRE
}

\author{
Indah Miftah Awaliah \\ Universitas Islam negeri Alauddin Makassar \\ Indah.miftah.awaliah@uin-alauddin.ac.id
}

\begin{abstract}
The aim of this research is to explore gender issues reflected in Jane Eyre written by Charlotte Bronte. Jane Eyre centers woman as the second sex under the domination of men. Woman autonomy is part of gender issues which becomes a concern of feminist. Descriptive qualitative method through library research was used in this research by applying a feminist literary approach. Through this approach, women issues were digged out. The data were collected from primary data and secondary data. Primary data are collected from the novel Jane Eyre by Charlotte Bronte, while secondary data are collected from books and journals that related to the topic. The result of the research shows that gender issues in the novel did exist and were reflected both through male and female characters and through classification of gender manifestation of woman and men.
\end{abstract}

KEYWORDS: Gender, Woman Autonomy, Masculinity, Feminity.

\section{A. INTRODUCTION INTRODUCTION}

iterature is a picture of human condition time by time. It Is a media to express the feelings and the arguments in specific ways. Culler (1997), argues that perhaps literature is like weed, which are simply plants that gardeners do not want to have

growing in their gardens. Mosse (1996), states that on the nineteenth century in England, there is an opinion that women are inappropriate to work outside the house to earn money. According to Guerin (1992), while some feminists have a problem with gender differences, others believe that the entire concept of female difference is what has caused female oppression; both of them wish to move beyond with difference altogether.

Gender has come to be applied in several ways; it has described woman's relationship to man in societies, the experiences of woman and man in movements in social emancipations. Gender are divide into masculinity and feminity. According to Faqih (1998), it caused woman as the second sex, and if it happend, it will be considered as a "fate" of woman and is a normal thing of her life. Furthermore, Sugihastuti (2010), mentions that Connel devided two kinds of masculinities; physical masculinity of working class and the technical masculinity of middle up class. Connel concludes that working class masculinity is always identified with physical while masculinity of middle up class is always identified with technical power (scientific or political).

The explanation of Connel above about physical power of masculinities, also makes an imaging concept of feminity. If men appear with their physical power then women with their delicate nature. The combination of delicate feminity here can be seen such as a depiction of nails of women. In centuries, these long nails being denoted as an indication of women could not work too hard. 
The position of woman in society stands between a hope and reality. Most of women hope a justice of their position in every dimension of their life. Woman needs an autonomy for her life, she needs to make their own decision, such the woman's claim to control their own bodies, or the protest against inequality at home. Naqiyah (2005), argues the meaning of woman autonomy is a woman which autonomous and independent in every particular way about her health and body.

The researcher chooses Jane Eyre, one of the great novel from the $19^{\text {th }}$ century. Jane Eyre was famously known as an autobiography of a woman writer Charlotte Bronte. There are some researchers have been done on Jane Eyre. Most of them see from different point of views including the position of woman in 19th century related to the concept of existence and the relationship between Jane Eyre and Charlotte Bronte to her readers. No one focuses on the woman autonomy as part of women's "dreams" to change their position from subordinated to equalled group. This research tries to answer the gap.

There are various problems in Jane Eyre novel, such as the way of writer, Charlotte Bronte, keeps communicating with her readers, the clear depiction of the difference between the masters and the labors, the loneliness of Jane which makes her trying hard to find the relatives. In this research the researcher mainly focusses on woman autonomy aspect. The reason of choosing woman autonomy is because the main character of the novel, Jane Eyre, believes on the importance of woman's independence and strives to maintain a position in life, and to devoid of any debts to the other characters. Jane Eyre also looks for equal emotion with other character.

The aim of this research is to explore gender issues reflected in Jane Eyre written by Charlotte Bronte. This novel centers woman as the second sex under the domination of men. Woman autonomy is part of gender issues which becomes a concern of feminist

\section{B. REVIEW OF LITERARTURE}

According to Rowbotham (1992), the word feminist was invented by a French socialist, Charles Fourier, in the early nineteenth century. Firstly he imagined a new woman who would both transform and be herself transformed by a society based on association and mutuality, rather than being on a competition and profits. And this influenced of many women to reach their emancipation. Lips (2007), defines gender as a cultural expectations of man and woman, for example; woman are known as gentle, beautiful, emotional and motherhood. While man are considered strong, rational, manly and powerful. Faqih (1998), states that the characteristic of the character that possibly exchanged depends on reaction of the environment, for example, there is a soft behavior man and a strong, rational and mighty woman. The changement in the characteristics of these personal description may occur from time to time and from place to place. 
Moreover, Ruthven (1985), states that the thought and the feminist movements was born to ended the male dominations of woman in society. Through the thoughts and movements, feminism has to destroyed by the cultural structure, arts, church, laws, main family that consist of the power of father and country, even all the images, institutions, customs, and the various habitual that makes woman as an unappreciated unseen victims. According to Humm (2007), feminism combined the doctrine of equality then starts to making an organized movement to reach the woman rights, with the dreams of woman worlds.

\section{METHODOLOGY}

\section{Type of Research}

This research will use descriptive qualitative method. Descriptive qualitative method is a method that will give a better understanding by describing the entire phenomenon that is search for. The aim of this method is to analyze the data that come from the novel. Feminist theory will be used by the researcher to find out the relation of woman autonomy in the society to anything that gives the character of Jane, including her point of view which probably as the background of her actions to make a decision of life.

\section{Source of Data}

The data used by researcher in this research taken from Charlotte Bronte novel Jane Eyre, published in 1847 as the primary data. The secondary data are previous studies that related to the topic and the supporting data that will be taken from various books, articles, and website on internet. By the supporting data, the researcher collects and used them as they are related to the topic.

\section{Method of Analyzing Data}

The researcher reads the data comprehensively and makes list of data by classifying the data based on their relevance and significance. All data are studied and analyzed by comprehend readings and deep understanding based on the related and appropriate approach. Then, as the result of analysis, the data are interpreted through description based on the subject matter, the gender issues related to Jane Eyre's novel By Charlotte Bronte. In analyzing the data, the writer will use feminist theory based on feminist literary criticism.

\section{FINDINGS}

\section{The Image of Women in Jane Eyre}

In a family, man could run his function as a financial source in the family without any help of woman. To do so, woman has a household job and child care at home. The woman position as the second sex makes man to be an important position. It is a normal thing if man keeps both working outside a house and also caring for children.

According to the novel Jane Eyre, the image of women always stands behind the men with the social class variations among them. It clearly shows that women mostly doing a household job rather than being a financial resources in a family. Even though Jane Eyre in 
an exception in this topic, she is trying her best to make her own financial by working as a governess which in that time, the occupation of governerness itself could raising Jane's position in society. It can not be denied that Jane still relies on men's characther.

As in many eighteenth and nineteenth century novels, virtue and inner worth are ultimately recognized by inheritance and through marriage, a rise in economic fortunes. Eventhough Jane Eyre is something different: a novel is about woman written with man's freedom, the freedom to potrays the impoliteness of a heroine who has outbursts of anger as a child and uncontrollable passion as an adult. Jane confesses her desire openly when she thinks it is hopeless and refuses the passive and dependent role in romance. All this violated deeply raised social codes of feminity and respectability.

The analysis of women position in this chapter will be focussed on nine characters which have a high impact in the story. To do so, the analysis will be focussed on women characters that will be analyzed. They are Jane Eyre, Mrs. Reed, Bessie, Helen Barns, Miss Temple, Mrs. Fairfax, Adele Varens, Blanche Ingram, Bertha.

\section{The Image of Men in Jane Eyre}

The gender assumption of men in Jane Eyre is bounded tightly to the sex of male and female. The man character treats woman character according to his experience background, motive, and relationship acknowledge that is needed between man and woman. On the contrary, woman receives and responses to the man's treat based on her comprehensions about the position of man related with woman.

The researcher analyses this gender assumption in the novel Jane Eyre. The analysis in this chapter is focussed on the discussion about the image of men. The analysis is already done by the description or even the character that related to the gender assumption that exists on the novel. According to the intensity of the character and the appearance of men's character, there are four characters that are analysed in this chapter. They are John Reed, Mr. Brocklehust, Mr. Rochester, Mr. St. John Rivers.

\section{Gender Issues in Jane Eyre}

Why "gender" and not "feminist"? Gender term consists of social role either women or men. The relation between men and women is important to determine their position. The jobs which is men and women do in certain communities are determined by social class, gender and ethnic group. Most of women also live in family and gender role in family represents a particular aspect of woman in living the world. In making decision, access to resources, division of work, and relationship outside the family, all of them may be decided by gender relation in family.

"Meantime, let me ask myself one question. Which is better? To have surrendered to temptation; listened to passion; made no painful effort-no struggle; but to have sunk down in the silken clime, among the luxuries of a pleasure-villa. . . 
. oh yes, he would have loved me well for a while. He did love me-no one will ever love me so again. I shall never more know the sweet homage given to beauty, youth, and grace- for never to any else shall I seem to possess these charms. He was fond and proud of me-it is what no man besides will ever be" (p. 416).

"But where am I wandering, and what am I saying, and, above all, feeling? Whatever it is better. . fevered with delusive bliss one hour-suffocating with the bitterest tears of remorse and shame the next-or to be a village school-mistress, free and honest. . . yes; I feel now that I was right when I adhered to principle and law, and scorned and crushed the insane promptings of a frenzied moment. God directed me to a correct choice. I thank His providence for the guidance" (p. 416).

The analysis about gender also indirectly declares the necessary of men involvement to understand and support the change in gender relation. This is to achieve an equal position between men and women in society.

To find out the gender issues in Jane Eyre novel, the researcher will devide the analysis into several parts; the first one is gender manifestation of women and the second one is gender manifestation of men. This division is a simple way to find out the actions that reflect the power, frustation, individualism and the way of speaking. The analysis cosists of five main concepts of gender analysis; the problem of gender differentiation, the gender gap, genderization, gender identity, and also gender role that reflects the role of women or the position of men that applied in society.

\section{Gender Manifestation of Women}

Gender differentiation has built an injustice of gender position of women. The injustice of woman is devided into six parts. Firstly, the subordinate of woman in front of man, specially in case of making any decision of life and controlling power. Secondly, dissimilarity and gender distribution of the marginalization of women giving birth of economical findings among environment, bureaucracy, and development programs. Thirdly, this dissimilarity result is the suppression of woman. Fourth, woman practically works inside the house, do any domestic work at home and if they want to work outside the house. It means that they would reach a double job (caring for a child and as a employe). Fifth, gender dissimilitation also makes any violence both physically and mentally for woman. Sixth, all gender differentiation above, according to Faqih (1998: 151), it caused woman as the second sex, and if it happend, it will be considered as a "fate" of woman and is a normal thing of her life.

"We were born to strive and endure-you as well as I do so. You will forget me before I forget you" (p. 369).

The quotation above is a declaration of Jane about her complicated relationship with Rochester. Moreover, Jane makes her own decisions to Leave her master, leave Thornfield to survive with her principles: 
"What was I? in the midst of my pain of heart, and frantic effort of principle. I abhorred. I had no solace from self-approbation, none even from self-respect. I had injured, wounded, left my master. I was hateful in my own eyes. Still I could not turn, nor retrace one step. God must have led me on. As to my own will or conscience, impassioned grief had trampled one and stifled to other. I was weeping wildly as I walked along my solitary way; fast, fast I went, like one delirious. A weakness, beginning inwardly, extending the limbs, seized me, and I fell" (p. 374).

Jane's position as the main character of the novel, sometimes has a brightly imagination of her position. Here the researcher puts a simple quotation of Jane's imagination if she was a man:

"It seemed to me that, were I a gentlemen like him, I would take to my bosom only such a wife as I could love; but the very obviousness of the advantages to the husband's own happiness, offered by his plan, convinced me that there must be arguments against its general adoption of which I was quite ignorant, otherwise I felt sure all the world would act as I wished to act" (p. 222).

Associated with injustice of woman that caused by differentiation and gender division, the researcher will analyze some problems that concluded as gender manifestation of the novel Jane Eyre. These problems are : First, the traditional role of women as mother, wife, housewife and workers. Second, the women's addiction of men. Third, women as a second sex. Fourth, the limitation of women's movements.

The Traditional Role of Women as Mother, Wife, Housewife, Workers.

Men and women do different kind of jobs, even though the duties of each gender change by time. Gender division of labour, and this decision was made by development planners.

The difference in the form of family, family structure, marriage arrangement, political structure and economic makes women practically have job to give birth and raise a child. Women also practically have daily jobs as a housewife.

"Women are supposed to be very calm generally: but women feel just as men feel. They need exercise for their faculties, and a field for their efforts, as much as their brothers do. They suffer from too rigid a restrain, too absolute a stagnation, preciesly as men would suffer; and it is narrow-minded in their more privileged fellow-creatures to say that they ought to confine themselves to making puddings and knitting stockings, to playing on the piano and embroidering bags. It is thoughtless to condemn them, or laugh at them, if they seek to do more or learn more than custom has pronounced necessary for their sex" (p. 95).

The quotation above is a kind of a radical feminism, an example view of men and women during the Victorian, patriarchal, time of Charlotte Bronte wrote the novel. It 
shows Jane's longing for equality and independence; a rebellious feminism. This quote is also a way for the author to express her longing for less restricted life and her feministic view through her protagonist.

\section{The Women's Addiction of Men.}

Based on the novel Jane Eyre, in some events the addiction here contains the relationship among Jane with Mr. Rochester and Mr. John Rivers. The researcher concludes that the character of Jane using her addiction as the background of her movement, starts to find her own financial income then her feelings.

\section{Women as a Second Sex.}

Furthermore, in nineteenth century as the throwback time when the author wrote this novel, she expressed her feelings about woman's position. Family is the smallest unit of community. The woman's position has to go through some filtering. Even in the house, woman has to face the "power of man". The power which practically makes man has an authority for the whole things in the house. Then, as an independent woman who feels really annoying with "the power of man", she tries to create some confrontations of this unequal position. This is the example of a strong voice of Jane. What she wishes for is about a woman positions. Jane certainly does not understand anything about gender manifestation, feminism, woman position or anything related to it, she has never got a specific education about that. It means that she does not realize about woman autonomy. She just imagines how nice it would be, if woman has an equal movement which is the same with man does.

"Nobody knows how many rebellions, besides political rebellions, ferment in the masses of life which people earth. Women are supposed to be very calm generally; but women feel just as man feel; they need excersise for their faculties, and a field for their efforts, as much as their brothers do; they suffer from too rigid a restraint, too absolute a stragnation, precisely as men would suffer . .." (p. 130).

\section{The Limitation of Women's Movement}

The oppression that happened in Jane's life is actually as the background that she makes some rebellions. Started from the strong voices she created in her mind then moving to real actions of movements. Here the researcher puts a piece of quotation when Jane craves for a new place after served eight years at Lowood Institution and started to advertise herself.

"I sat up in bed by way of arousing this said brain; it was a chilly night; I covered my shoulders with a shawl, and then I proceeded to think again with all my might . . . What do I want? $A$ new place, in a new house, among new faces, under new circumstances; I want this because it is of no use wanting anything better. 
How do people do to get a new place? They apply to friends, I suppose; I have no friends. There are many others who have no friends, who must look about for themselves and be their own helpers; and what is their resource?" (p. 102)

The realization of her strong voices can be identified from the way she stands out for her pride and rights to declare an argument and a freedom of making a decision for her own life even a decision for both suitors whom to be married (Mr. St. John and Mr. Rochester marriage proposals).

\section{Gender Manifestation of Men}

The relationship between man and woman in Jane Eyre can be seen in their position and activity on both sexes. On the smaller relation between man and woman, the person whose both snatch the position is as a dominant. Moreover, on the bigger relationship area, society does the same thing. Their effort between man and woman really happen in more complex reationship. The fact is, the men are more powerfull as a dominant than women. The following is Rochester's declaration when Jane refuses his marriage proposals:

"No man being injured by the branch? For you have neither relatives nor acquaintances whom you need fear to offend by living with me" (p. 369).

In analyzing about gender, indirectly has a correlation with oppression. The oppression that mostly comes from male dominations of women and children in family and then spreads in society. This terms is always called patriarchy.

\section{Men as The First Dominant Sex in Family}

Dealing with the first dominant sex in family, the researcher found it on the character of John Reed, the causin of Jane. Reed's character shows how he controll every thing in the house including her mother. It makes him as the leader of the house. He tries to put Jane as his slave, he controll and commands Jane to do whatever he says.

The second character that researcher finds functions as the first dominant sex in family is Mr. John Rivers. He is the relative of Jane too. He controls everything in the house, his sisters, including Jane when Jane was at Marsh End and St. John refuses to regard Jane as his "sister". He even insists on marriage that will bring the strong union between both of them:

"I . . . do not want a sister: a sister might any day be taken from me. I want a wife: the sole belpmeet I can influence efficiently in life, and retain absolutely till death" (p. 359).

\section{Men as The First Dominant Sex in Society}

The most strong first dominant sex in society can be seen on the character of Mr. Rochester. He is the master of Thornfield Hall and also the master of Jane. He manages everything in society. Social class and economic reason make him as the first dominant sex 
in society. He has the power to controll everything. Under his management, Thornfield hall increases and is more liveable.

The next dominant sex character in society is Mr. Brocklehurst. Jane Eyre clearly shows his power of controlling everything. A higher social class and also his position as the leader at Lowood Institution become the reason he can controll everything, including teachers and his popils. There are several events that he tries to push Jane; starting from a wrong information he spreads, and until punishing Jane for some of her mistakes.

\section{E. DISCUSSION}

In related to the main topic of this research, the researcher found that Jane Eyre as the main character in the novel has gone through to some gender manifestations around her environments. Jane Eyre has made some confrontations with other characters. As long as she is looking for her true identity, she is learned to be independent, stands on her own feet, and reaches her own financial resource. She has been trying very hard for her freedom, starting from Gateshead, then Lowood Institutions, then moved to Thornfield Hall. In some cases she was runaway at Marsh end.

Her transformation can be said quite fast. She was transformed in one night, when she was a girl at Gateshead. Her environment at Gateshead forces her to act wiser than the kid on her ages. The treatment she got from her aunt and cousins has taught Jane about how to see the world. Their treatment also makes emptiness in Jane. The young girl has to face the world alone, she feels she had no family at all.

Through time she brings her emptiness with her, with no relatives she tries to build up her own relatives through friends, teacher, or even strangers. All the conflicts mixed with one achievement, woman autonomy. She tries really hard to reach it. She was tired of being under controll of someone. She wants to make her own decisions. Then at the end of the story, she finds her families, inherits some money, finds her true identity, and finds her lovely equal relationship that is love and to be loved.

\section{F. CONCLUSION \& SUGGESTION}

In responding to the research question, the impact of gender issues in promoting woman autonomy against injustice of woman can be seen in the character of Jane. Jane keeps survive during her quest for identity and independence. The frightening night in the Red Room causes her growing up over night and having experinced true fear. She is no longer afraid of standing up for herself against the patriachal society.

To free herself in the patriarchal society Jane meets and overcomes: oppression by the Reed family and Mr. Brocklehurst, starvation at Lowood Institution and during her wandering before reaching Marsh End, madness in Red Room and at Thornfield hall and coldness by being lonely without any relatives, and being lonely by the way Mr. John treated 
her. At the end of the story, she finally finds the equal relationship she longs for with her master, Mr. Rochester.

The depiction of women oppression is vividly reflected in Jane Eyre. Eventhough each character of the story reacts in different ways. This novel has a lot of themes that could be analyzed by various theories. In other words, the researchers can analyze and find out the relevant problems, such as loneliness, loyalty, women role, social classes and other interesting problems in the novel Jane Eyre. The researcher suggests the next researchers might use Marxist feminist approach in analyzing the novel Jane Eyre to find out the impact of social classes which are completely bring massive injustice position in society. The researcher also hopes the next researcher might do the comparative analysis of the novel Jane Eyre but creates different plot in each story which are comes from two women writers in nineteenth century, then the result of the research might give a new contribution in literature study.

\section{REFERENCES}

Culler Jonathan. Literary Theory, A Very Short Introduction.New York:Oxford University Press. 1997.

Faqih Mansour. Analisis Gender dan Transformasi Sosial.Yogyakarta:Insist Press. 1998.

Guerin Wilfred. A Handbook of Critical Approaches to Literature $4^{\text {th }}$ Ed.New York:Oxford UP. 1992.

Humm Maggie. A Readers Guide to Contemporary Feminist Literary Criticism.New York.London:Harvester Wheatseaf. 2007.

Lips Hilary. Sex and Gender.New York:McGraw-Hill Humanities/Social sciences/Languages. 2007.

Mosse Cleves. Gender dan Pembangunan.Yogyakarta:Pustaka Pelajar. 1996.

Naqiyah Najlah. Otonomi Perempuan.Malang:Bayumedia Publishing. 2005.

Rowbotham Sheila. Women in Movement, Feminism and Social Fiction.Great Britain:Routledge, Chapman \& Hall. 1992.

Ruthven. Feminist Literary Studies : An Introduction.Cambridge:Cambridge University Press. 1985.

Sugihastuti. Gender \& Inferioritas Perempuan.Yogyakarta:Pustaka Pelajar. 2010. 